\title{
Science, Evidence, and the Resurrection
}

\section{S. Joshua Swamidass (D) in The Genealogical Adam and Eve}

https://doi.org/10.54739/urbi

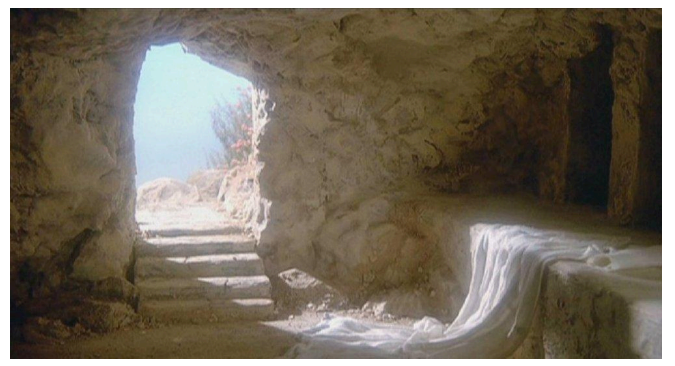

$S$ things because we trust the accounts of trustworthy sources.

Mass is energy. Time slows with gravity and acceleration. The earth moves around the sun at 67,000 miles per hour. Two black holes merged 1.3 billion years ago, sending gravitational waves through space that arrived last year at LIGO. In principle, this is all reproducible, but just in principle. If we personally verified and reproduced every experiment ourselves, science would grind to a complete halt. Yes, we emphasize evidence. But we usually trust the scientific consensus. Yes, we are skeptical and regularly challenge accepted theories. But we usually trust other scientists' reports of what they have seen.

I am a scientist. Still, on Easter, I celebrate that Jesus rose from the dead about two thousand years ago. This event, in first-century Palestine, is the cornerstone of everything. In the same way that trust-like faith in science is connected to evidence, so is the faith I have in the resurrection.

What is the evidence from which grew my trust? A brief and incomplete outline is included here. ${ }^{1}$ This evidence is not an answer, but it raises the question. All we need is curiosity.

1. Without the physical resurrection, two thousand years of history are left begging for explanation, like a movie missing a key scene.

I am often asked by my colleagues about evidence I see for the resurrection. This is how I explain it to them. Originally titled "Is There Evidence for Easter? A Scientist's List," this article was first published Easter of 2017, on the website of the Veritas Forums, then again on Easter of 2018. Then it was included as an appendix in The Genealogical Adam and Eve. by S. Joshua Swamidass. Copyright @ 2019 by S. Joshua Swamidass. Used by permission of InterVarsity Press, PO Box 1400, Downers Grove, IL 60559.

1. I recommend my personal entry point to this conversation: Josh McDowell, More Than a Carpenter, rev. ed. (Carol Stream, IL: Tyndale House, 2009). Other accounts may be more helpful to others. For example, N. T. Wright's more recent explanations of the resurrection ("Christian Origins and the Resurrection of Jesus: The Resurrection of Jesus as a Historical Problem"), which he expands into the book The Resurrection of the Son of God, were compelling to the philosopher Antony Flew before he died, even though he does not appear to have trusted Jesus in the end. Likewise, C. S. Lewis's argument for the resurrection in Mere Christianity convinced Francis Collins and, more privately, other scientists have responded similarly to C.S. Lewis's thoughts. I also thank Sean McDowell for his helpful comments on this list.
No other event in all recorded history has reached so far across national, ethnic, religious, linguistic, cultural, political, and geographic borders. The message spread with unreasonable success across the world. During just the first few centuries, it spread without political or military power, prevailing against the ruthless efforts of dedicated, organized, and violent opposition. How did a small band of disempowered Jews in an occupied and insignificant territory of ancient Rome accomplish this unequaled act? ${ }^{2}$ What happened so many years ago that reframed all human history?

2. With dates established by radiometric analysis, prophecies from centuries before Jesus' birth predict his life, death, and resurrection. ${ }^{3}$ The great scientist Blaise Pascal identifies this as the tangible proof for people who want evidence that God exists. These prophecies include specific details that Jesus and his followers could not control. For example, before the Romans invented crucifixion, Psalm 22:16 described the piercing of Jesus' hands and feet. Isaiah 53 is a particularly important prophecy that lays out the story of Jesus and the meaning of the resurrection (Is 52:13-53:12). Is this evidence of an Intelligence outside our time confirming Jesus' authority?

3. Jesus was a real person in history who died. Several manuscripts from multiple sources, including Jewish historians, describe a man named Jesus who lived and was executed. ${ }^{4}$ Specific details reported about his execution confirm "blood and water" spilled from a spear wound in his side. He really died and was not merely unconscious. ${ }^{5}$

2. "The Christian Origins and the Resurrection of Jesus" by Wright in 1998 is an excellent exposition of this idea. The disciples themselves predicted this worldtransformative impact of the gospel too (Acts 5:38-39).

3. Bonani and others, "Radiocarbon Dating of Fourteen Dead Sea Scrolls" Radiocarbon 34 (1992):843-49.

4. A good study on this is The Jesus Legend: A Case for the Reliability of the Synoptic Jesus Tradition by Paul Eddy and Gregory Boyd (Grand Rapids: Baker Academic, 2007). A related work is Did Jesus Exist? by Bart Ehrman (New York: HarperOne, 2013). The latter is by an agnostic author and does not argue that Jesus is divine. I still include it here to demonstrate that the evidence is so strong that Jesus existed that we do not need to start with Christian commitments to see this truth.

5. The report of his death explains "blood and water" poured from his side when he was wounded (Jn 13:1-19:42). This is an unusual detail that is atypical of death by any means, including crucifixion. The "water" can be understood with modern medicine as the result of necessarily fatal wound that released clear fluid that had abnormally collected around his lungs or heart (William D. Edwards, Wesley J. Gabel, and Floyd E. Hosmer, "On the Physical Death of Jesus Christ," JAMA 255 [1986]: 1455, https://doi.org/10.1001/jama.1986.03370110077025). Other than to accurately report what had been seen at his death, there is no reason to include this difficult to explain detail about his death that we only now can understand. 
4. The early accounts of the resurrection and prophecies predicting it were reliably transmitted through history. As of 2014, more than 66,000 early manuscripts are known, orders of magnitude more than other ancient texts. Many are carbon dated to before Jesus' time on earth and the first few centuries after. We see accounts nearly unaltered in the earliest manuscripts. ${ }^{6}$ A pattern of consistency emerges. There are variations in the manuscripts, but nothing invalidates the reliability of the resurrection accounts.

5. Accounts of the resurrection include inconvenient and unflattering details, which make most sense as attempts to reliably record what had happened, free from embellishment. They do not fit expectations of a fabricated account. For example, women are the first witnesses of the resurrection. In a culture that did not admit the testimony of a woman as valid evidence in court, this detail is surprising. Likewise, all the disciples, the leaders of the early Church, flee as cowards when Jesus is taken.

6. After Jesus' violent death, his followers were frightened and scattered. Then, something happened that grew a strong, bold, and confident belief that resisted sustained, murderous opposition. Unlike other movements with executed leaders, once the disciples came back together, they did not replace Jesus with one of his family members. Their resistance was entirely nonviolent and devoid of political power. Yet they were all suddenly willing to die for what they saw. What changed them? Why was there not evidence at the time to undermine their belief? ${ }^{7}$ What convinced them that Jesus was inconceivably greater than his family?

7. More than just a fact about our past, the resurrection creates a connection to God that is perceived by people from all times, cultures, socioeconomic statuses, personalities, and metal capacities, across the last two thousand years of history. Its reach includes some of the most famous scientists: Blaise Pascal, Johann Kepler, Robert Boyle, Gregor Mendel, Asa Gray, Michael Faraday, James Maxwell, Santiago Ramón y Cajal, and

6. The actual history of the Bible is more interesting than the fiction. Sometimes it is messier than we imagine, but a God who raises Jesus from the dead can certainly preserve his message to us in history. Unlike fictional accounts of the Bible's history (e.g., Dan Brown's The Da Vinci Code), Reinventing Jesus by J. Ed Komoszewski (Grand Rapids: Kregel, 2006) covers the historicity of Jesus. "The Bibliographic Test” by Joshua McDowell and Clay Jones, August 13, 2014 ( https://www.josh.org/wp-content/uploads/Bibliographical-TestUpdate-08.13.14.pdf) gives a good overview the manuscripts in question, including recent new discoveries.

7. The Fate of the Apostles: Examining the Martyrdom Accounts of the Closest Followers of Jesus by Sean McDowell (London: Routledge, 2015) is most complete account of their confidence. Apparently, not all died for their faith, but it appears all were willing to die.
Francis Collins. Is this unmatched reach and influence a sign of a living God working his purpose in history? ${ }^{8}$

Some of the evidence here is established by scientific methods. For example, radiocarbon dating demonstrates that Isaiah 53's prediction that Jesus "see the light of life" after dying was written at least one hundred years before his birth. However, the question of Jesus gently beckons us out from science's limits, into a reality where love, beauty, goodness, and relationships are real. In the question of the empty tomb, science itself reaches its hard limit. It points to something beyond itself.

1. The resurrection is God's direct, supernatural action in a specific physical event in history. The obvious finality of physical death (both in modern science and to the ancient world) serves to highlight the role of God in this moment. We never consider God's action in science, so we cannot even ask the question without opening our minds to things beyond science. ${ }^{9}$

2. The entire Christian faith hinges on the physical resurrection of Jesus (1 Cor 15:14,17), but no "resurrection mechanism" for science to study is proposed. As a mechanism-free singular event that defies all natural laws, we are well outside science's ability to adjudicate facts and understand evidence.

3. The question of the resurrection is more like an opportunity to fall in love than a scientific inquiry. There is evidence, but the resurrection cannot be studied dispassionately. ${ }^{10}$ If Jesus really rose from the dead, it reorders everything. Just like falling in love, in changes our view of the world.

The final verdict, for me, is that the resurrection makes sense through the lens of history. I find the Creator of all that science studies comes to us in this way. The evidence is compelling, but not definitive. Faith in Jesus is reasonable and is certainly not without evidence.

So, we are left with an invitation. Will we too believe? Will we be curious? Will we respond with trust?

8. For those curious about science, For the Glory of God: How Monotheism Led to Reformations, Science, Witch-Hunts, and the End of Slavery by Rodney Stark (Princeton, NJ: Princeton University Press, 2003) explains Christian belief among early scientists and its foundational role in science. Even the "father" of modern science, Francis Bacon, was a Christian and explained in Novum Organum from Christian theology that science is an effort to take down intellectual "idols."

9. This rule of avoiding appeals to God's action in science is often referred to as "methodological naturalism," but this is a misnomer. This rule that has been firmly established in modern science for hundreds of years, and was originally placed in science by Christians like Kepler, Bacon, Pascal, and Boyle for theological reasons. Their conception of science was not rooted in naturalism, but in their faith as Christians, so referring to this rule as methodological naturalism, as if it was a product of naturalism (and atheism), is not correct.

10. To be sure, Christians can correctly attempt dispassionate study in their academic work; see, for example, Michael Licona, The Resurrection of Jesus: A New Historiographical Approach (Downers Grove, IL: InterVarsity Press, 2010).

\section{References}

Josh McDowell, More Than a Carpenter, rev. ed. (Carol Stream, IL: Tyndale House, 2009).

N. T. Wright, "Christian Origins and the Resurrection of Jesus: The Resurrection of Jesus as a Historical Problem,", 1998.
N. T. Wright, The Resurrection of the Son of God, 2003.

C. S. Lewis, Mere Christianity, 1952.

Georges Bonani, et al. "Radiocarbon Dating of Fourteen Dead Sea Scrolls" Radiocarbon 34 (1992):843-49. 
Paul Eddy and Gregory Boyd, The Jesus Legend: A Case for the Reliability of the Synoptic Jesus Tradition (Grand Rapids: Baker Academic, 2007).

Bart Ehrman. Did Jesus Exist? (New York: HarperOne, 2013.

William D. Edwards, Wesley J. Gabel, and Floyd E. Hosmer, "On the Physical Death of Jesus Christ," JAMA 255 [1986]: 1455, https://doi.org/ 10.1001/jama.1986.03370110077025

J. Ed Komoszewski, Reinventing Jesus (Grand Rapids: Kregel, 2006.

Joshua McDowell and Clay Jones, "The Bibliographic Test,"'" August 13, 2014 ( https://www.josh.org/wp-content/uploads/Bibliographical-TestUpdate-08.13.14.pdf
Sean McDowell, The Fate of the Apostles: Examining the Martyrdom Accounts of the Closest Followers of Jesus (London: Routledge, 2015).

Rodney Stark, For the Glory of God: How Monotheism Led to Reformations, Science, Witch-Hunts, and the End of Slavery (Princeton, NJ: Princeton University Press, 2003).

Michael Licona, The Resurrection of Jesus: A New Historiographical Approach (Downers Grove, IL: InterVarsity Press, 2010). 